DOI: https://doi.org/10.46991/AFA/2021.17.2.040

\title{
IRONY IN FAN FICTION
}

\author{
Zaruhi Antonyan* \\ Yerevan State University
}

Irony is a broad concept with many cultural and artistic manifestations of criticism, sarcasm, humor, parody, and even tragedy. It can represent various intellectual and emotional states, such as criticism, self-criticism, curiosity, entertainment, disappointment, anger, boasting, etc. The tone, intensity and frequency of sound are sufficient to convey irony in speech. However, in writing authors use a number of linguistic and stylistic means to be able to convey irony to the reader. This also refers to fanfic (fan fiction) - a work of art/fiction written by book fans, TV series, films, etc. - which is based on an original creation and uses irony widely. The language we perceive when reading fan fiction influences our language and our own production of speech. Hence, the present case study aims at revealing ways and means as well as reasons of expressing irony in fan fiction - a discourse variety that has attracted great interest in the modern world especially among the younger generation.

Keywords: Fan fiction, fandom, fan, verbal irony, situational irony, dramatic irony, sarcasm.

\section{Introduction}

It is a well-known fact that emotions serve as a kind of moderator between the world and its reproduction in the language of people. Emotions enclosed in words reproduce the emotional attitude of the person towards the world. Otherwise stated, emotions are always present in words, and when necessary, expressed through them. Irony is a way of expressing emotions. Emotions often accompany irony in different types of communication, increasing enjoyment, anger, sorrow, hopelessness and other feelings. Irony is very common in speech, plays, novels, poetry, media texts and other discourse types. It is a literary/stylistic/rhetorical device the main essence of which is saying one thing

\footnotetext{
*zaraantonyan@ysu.am
}

Received: 21.06 .2021

Revised: 16.08 .2021

Accepted: 22.09 .2021

This work is licensed under a Creative Commons Attribution-NonCommercial 4.0 International License.

(C) The Author(s) 2021 
but meaning the opposite. It may also have additional social and emotional functions like expressing certain contrary emotions.

Irony is widely used in fan fiction/fanfiction (also abbreviated to fan fic, fanfic, fic or ff). Fan fiction is a type of fictional text written by fans of any work of fiction, comic books, TV series, films, etc., where the author uses established characters, settings, or other intellectual properties from an original creator as a basis for his/her writing. Fan fiction ranges from a couple of sentences to an entire novel, and fans can both keep the original creator's characters and settings or add their own. Since fan fiction has become popular relatively recently, people from all over the world can submit their works on social networks, availing the readers of an opportunity to study irony in more modern works of fiction.

\section{Irony: definition and types}

Most people have a general understanding of irony but there are also a lot of misconceptions about it. Henry Watson Fowler states that irony might have hundreds of definitions and very few of them would be accepted but what the definitions must necessarily include is that the surface meaning and the underlying meaning of what is said cannot be the same (Fowler, 2003). He believes that irony as an utterance postulates a double audience - a party that hears and does not understand and another party that hears and understands more than is meant (Fowler, 2015). Eric Partridge (1999) claims that irony states the contrary of what is meant. Considering the mentioned definitions, we would add that irony is a literary device in contrast or inappropriate between anticipations for a situation and reality. This can be a difference between the apparent meaning of something that is said and the underlying meaning. It can also be a difference between what might be predictable to happen and what actually ensues.

The term irony has its roots in the Greek comic character Eiron, a clever underdog who by his wit repeatedly triumphs over the boastful character Alazon (Irony, 2021). The Socratic irony of the Platonic dialogues derives from this comic origin. The word irony came into English to denote a figure of speech in the $16^{\text {th }}$ century as similar to the French ironie. It derives from the Latin ironia and ultimately from the Greek sipwveía eirōneía, meaning dishonesty, deliberately exaggerated ignorance (Eiron, 2021).

There exist three different types of irony: verbal, situational, and dramatic (Three different types of irony, 2021). Each has a different definition and 
function in fiction. Verbal irony arises when what is said is different from what is meant. Its intentional character gives the speaker a chance to hope that the audience will recognize the presence of irony. It should be noted that verbal irony is not lying. A lie is a falsehood meant to deceive. This type of irony is much less wicked. Sarcasm is perhaps the most distinguished sub-type of verbal irony. It is an ironic statement meant to mock or ridicule another person. Sarcasm is "designed to cut or give pain" (Sarcasm, 2011). Situational irony occurs when what happens is the opposite of what we expect to happen. It can be as simple as holding an umbrella outside only to find the sun shining. It can even be as dramatic as revealing the killer to be the least likely suspect. Dramatic irony occurs when the audience, having been given more information, understands a situation more clearly than the characters do. This understanding often leads to an element of suspense because we know the character will learn the truth eventually but we don't know when or how.

In the following part an attempt will be made to reveal how irony is expressed in fan fiction.

\section{What is fan fiction?}

Fan fiction is usually described as a derivative of a certain media artifact. This means that there ought to be a source-text which creates a response - fan fiction. This is nothing new and has been happening since mankind began creating artifacts. Not all stories repeatedly recreated by various authors are considered a form of fan fiction, because if this were the case then all re-written variants could be considered a form of fanfic. Re-imaginations might be born out of fandom, out of an intense appreciation of the original artifact. However, there is a difference in the goals set by authors. In that sense, fan fiction is just written for fans, and not for a market of consumers. Of course, reinterpretations might be promoted as treats for the fans, but actually they are meant to attract an audience as big as possible. The difference is clear: reinterpretations are aimed at a market with a wide audience, fan fiction is aimed at a fandom and its fans.

But what is fan fiction, if it is not a reinterpretation? Abigail Derecho (2006) offers an interesting way of approaching fan fiction. She calls the type of writing associated with fan fiction archontic. The word archontic is based on the idea of texts being archives. It is taken from Jacques Derrida's work Archive fever (1995) in which the author claims that incorporating the knowledge deployed in reference to it, the archive augments, engrosses and gains in 
auctoritas. But it also loses some absolute and meta-textual authority it has. Thus, archontic is the most accurate description of what fan fiction means in relation to the original artifact. If we see the original work as an archive, we can approach fan fiction as an entry to this archive. Hence, fan fiction is often described as a derivative. This description has several connotations that go along with it. The connotations, whether negative or positive, present a nonneutral starting point in a debate about fan fiction. Saying that something is a derivative implies that in the process of coming into existence it has lost something of the original work it is based on, thus becoming somewhat inferior to the original. By describing texts as archives, we do not have to deal with these connotations but instead see the text as an entry to an open archive with the original artifact as the basis for the same archive.

Thus, fan fiction is done by the fan for the greater good of his or her fandom, as opposed to other inter-textual reinterpretations which are done by professionals for a general audience. It is archontic literature, which means that a work of fan fiction contributes to the archive established by the original work or artifact on which the fiction is based. But how is fan fiction created, what rules and habits constitute an overall work of fan fiction? This poses a problem because we cannot talk about fan fiction, draw conclusions on it by establishing it as archontic literature without giving concrete examples about what it actually is.

To show what typical fan fiction is, I will represent a small sample - a piece of fanfic based on George Orwell's 1984 (2003) called An Alternet Ending, written by James Masters (2012), a member of Fanfiction net, one of the biggest on-line communities dedicated to fan fiction. The story itself is pretty short, that is why I have chosen to bring it here in full instead of adding it as an appendix.

Winston's body was racked with pain from the previous beating but his mind was still resisting. He knew in his heart that this was wrong and so his anger turned to his strength to push on and instead of taking the beating the following day he would strike back at them with full force. Threw his anger he ignored the pain and the betrayal. His eyes hardened to a light stone like blue and he was going to fight. When the thought officers came to get him in his cell he just smiled at them when one tried to wipe that smirk off of his face. The only thought going threw his mind was 'Either now or never.' 
He caught the hand as it sailed towards his face and struck back with vengeance at his tormentors left temple. A sickening crunch reverberated around the cell as the officer fell over dead. Winston's eyes got dark as the second officer tried to pull out his taster to stop him dead in his tracks but he was too slow and before the officer knew it he was on the ground getting the shit beat out of him. With one officer dead and the other knocked out Winston took their clothing and went incognito out of the ministry of secrets. Numerous officers tried to stop them but they meant the same fate as all of the others stopped dead with a bullet in the head. A single thought was going threw his mind 'When the people are afraid of the government that is tyranny and this is tyranny.' Many other people saw what he was doing and some decided to join him as they fought to the officials palaces ransacking and killing all that big brother was. Finally they made it to the center of the city and stormed the main buricratic building. The cowered that was big brother was under his desk whimpering like a little baby for all of this to stop. Winston just said to him "You disgust me." Everyone that was there agrees that Winston was the hero now that Big Brother and all of his corrupt government were finally over. It has been twenty years since the rebellion and the people have not been happier, light seems to have returned to the streets and I am happy that Winston made that difference. Things would be a lot different if he did not stand up and fight to become the first president of a new order on that the government is afraid of the people. A government can only go so far before the people decide enough is enough and revolt against the government. For we hold these truths to be self-evident.

The first thing we notice when we read the story is a certain freedom with the source material. What is presented here is an alternative ending to George Orwell's novel. In the original story, the protagonist Winston Smith is resisting the party doctrine of super-state Oceania through his journals, something that is highly offensive and will be answered with death penalty. He starts a love affair with Julia, thinking the Thought Police - Oceania's intelligence on people who 
might challenge authority - is not aware of his rebellion and his affair. When Winston and Julia get caught, Winston is severely beaten and tortured after which he is to be rehabilitated for reintegration into Oceania's society. The story above takes place during the torture-sessions Winston had to endure. Instead of taking the beatings, Winston stands up and defends himself from the beatings the Thought Officers would give him. He strikes them down, and rampages out of the Ministry of Secrets to establish a new order where the government is afraid of the people. First of all, it is not clear if Banker has read the original story correct. For example, there is no Ministry of Secrets. The Ministry where Winston is held in the original story is thought to be the Ministry of Love, one of the four ministries in Oceania. Also, it would be almost impossible for Winston to escape the ministry for several reasons: he was not aware of how the ministry was structured and therefore could not possibly coordinate a successful escape - telescreens would be able to see him trying to dress up incognito and see through his ruse. However, in fan fiction, what is and what is not possible does not matter. This is fanfic describing something that does not happen in the original story. James Masters (2012) explains his motivation for writing this alternative ending at the beginning of his fanfic:

Hey guys I have posted a little story to keep you busy, I just finished reading 1984, and good book in itself but the ending was something to be desired for. I honestly hope you can read 1984 by George Orwell. Well you know the drill I do not own anything of George Orwell except for the printed copies of Animal Farm and 1984.

It should be noted that the author of this piece turns to the knowledge of his audience when disclaiming the copyrights of Orwell's heritage. This is an example of how fan fiction is mostly written by fans for fans. In addition, the lack of professionalism (without judging its value) shows in the writing. Spelling mistakes are common throughout the text and there are several other mistakes that show the story is written by a fan, more than a professional.

In the following part of the paper some works of fan fiction accompanied by irony are represented and certain extracts taken from these works come under study. 


\section{Irony in fan fiction}

The famous scene from the cartoon The Lion King called What Ghost Mufasa Should Have Said to Simba (2013) by Super Fanfic Entertainment depicts how Rafiki leads Simba to a pool of water and asks him to look into it. At first, Simba sees nothing, but then he sees the image of his father. Mufasa's ghost rises and addresses his son from the sky, telling Simba that he is the one true king. And that is all Mufasa's ghost says in the cartoon. We propose to pay attention to the title of the fan fiction, it says: What Ghost Mufasa should have said to Simba. That is, according to the author, in the cartoon, the ghost of Mufasa left something unfinished in his speech.

Mufasa then reappeared again quickly. "Oh....and one more thing you should probably know. Scar was the one who killed me. He threw me back into the stampede." Simba then made an angry face. "SCAR!?HE....HE WHAT!?"

The author clearly speaks ironically about the creators of the cartoon who, in his opinion, have missed an important detail. But if analyzed without relying on the author's own thoughts, the whole situation is ironic for Scar who kills Mufasa since Simba wants to take revenge. This leads us to poetic Irony.

There is another example, this time of structural irony. We already realize: Simba was convinced that it was he who was to blame for the death of his father and not Scar. And Mufasa's words Oh.... and one more thing you should probably know hint at Simba's lack of intelligence, who was obviously surprised to hear this.

"Why didn't you tell me Scar murdered you sooner!?" Simba said angrily. "Well for starters, you were just a cub, you didn't have the strength to take him on." Simba looked at the ground. "Huh....oh yeah."

This is of course an ordinary dialogue and an ordinary question if we surely do not forget the fact that Mufasa died when Simba was still small, which once again leads to Simba's lack of intelligence, but not only Simba's. In the cartoon when Rafiki asks Simba to look at his reflection in the water and says that Mufasa lives in him, it means that what the alleged ghost of Mufasa says are in fact Simba's forgotten thoughts. Let us pay attention to the punctuation of the sentence Why didn't you tell me Scar murdered you sooner 
(!?). This punctuation is actually for readers pointing to the obviousness of the answer (again for readers). So, it is not only structural irony but also sarcasm.

During the reign of Scar in the cartoon, stocks of food and water were empty, hyenas swarmed in the kingdom. And at the same time, while Mufasa was alive he kept telling Simba that he was the Future King. But here Mufasa admits that the one who killed him and tried to kill his son was not a bad king at first but he gradually spoiled everything and that is why he decided to appear and tell Simba that Scar had killed him and the real king was Simba. We must also pay attention to the fact that Mufasa speaks casually using slang (screw things up) that is not characteristic of his character in the cartoon. Here we deal with verbal irony.

Plus you seemed really happy with your new life with Timon and Pumba. I figured I'd let you know when Scar completely screw things up, which he did. Believe it or not, he wasn't a bad king at first. But the problems slowly increased.

"Sorry father. Just one last question. What's death like?" "Painful...and a little stupid." "Stupid?" Simba said puzzled.

"How come Zazu can survive being sat on by a heavy rhino, but I die in a stampede?"

Simba shrugged. "Cartoon logic."

Zazu is an uptight, red-billed hornbill that served as King Mufasa's majordomo, and the begrudged caretaker of Simba. When Simba and Nala (lioness cub) escaped among the animals to the elephant cemetery, Zazu was supposed to watch over them but lost them of his sight and began to move around animals that were ten times larger in size. But when Mufasa (the lion) got in a stampede, he was injured and died. In example 6 the author of the fanfic teases the Cartoon logic which has become a fairly common statement on the Internet.

Now let us discuss another example from Fanfiction net - Fairy Tale Stereotypes by Foosemittee (2013).

"I am tired," the innkeeper's daughter growled, "of these unrealistic tales. Tell them to your children, but don't tell them here!" The group of travelers turned towards her. “What's the problem with fairy tales?" a young, haughty lad asked. The innkeeper's daughter smirked. 
"You must know little of the ways of men," she replied. "Or the ways of princes."

"Enlighten us," he replied.

“Well, princes and peasants don't kiss, for one," the girl announced, rearranging her skirts daintily. "And if, perchance, a prince were to want to 'kiss' a peasant, well...he wouldn't be considering marriage, exactly." "Probably'd have other things on his mind," another woman agreed. There was quite a bit of laughter at this. "And a prince can marry who he chooses," a hooded stranger added. The happy group looked up.

“True," the innkeeper's daughter agreed, though she would have admitted that she knew nothing of princes if she had been asked.

“...what they do, you see, is they choose the most beautiful maiden, and then they claim she has a title so that other commoners won't be lining up to try to seduce them," the stranger said quietly.

"And that, ladies and gentlemen," the innkeeper's daughter announced, "is why you should never trust a prince! Honestly, that can't be true, can it?" she asked the stranger. He stood, drawing back his hood and revealing his golden grown.

"You'd best start believing in fairy tales, girl," he growled. "You're in one." Suddenly the moonlight shone into the room, lighting on everyone present. The innkeepers daughter reeled in shock, and then the whole room turned into pirates - I mean, fairies!

In the Sleeping Beauty, the one who awakens Aurora from her wretched curse and saves the day is Prince Philip. In The Little Mermaid the one who provides Ariel with refuge and a future life of luxury is Prince Eric. In Cinderella the one who gets her out of the mud and into wealth is Prince Charming. Surely, there exists a common trend. Fairy tales are a world of imagination and pleasure of a child, but they also serve as a source of inspiration and role model. Morality lies in the fact that the good always wins at the end, the prince comes and saves the heroine. But of course, morality lies not only in that, but also in being kind to everyone, being able to forgive, not 
letting the bad ruin your heart. Surely, not every child understands the essence of fairy tales if we do not bring it to them. Mostly, they get inspired by what they see or by what they are told.

"I am tired," the innkeeper's daughter growled, "of these unrealistic tales. Tell them to your children, but don't tell them here!" The group of travelers turned towards her.

Let us pay attention to the phrase unrealistic tales from the above passage by Foosemittee (2013). What is the meaning of the word tale in general? It can be explained as an imaginative narrative of an event - a story or an intentionally untrue report (Tale, 2011). Surely, it depicts something unrealistic. The author uses the phrase that contradicts itself. So, we have contradiction and verbal irony. Tell them to your children, but don't tell them here! is sarcasm as the innkeeper's daughter thinks that children believe in unrealistic tales.

Let us also consider the following examples:

"What's the problem with fairy tales?" a young, haughty lad asked. The innkeeper's daughter smirked.

“Well, princes and peasants don't kiss, for one," the girl announced, rearranging her skirts daintily. "And if, perchance, a prince were to want to 'kiss' a peasant, well...he wouldn't be considering marriage, exactly."

"Probably'd have other things on his mind," another woman agreed. There was quite a bit of laughter at this. "And a prince can marry who he chooses," a hooded stranger added. The happy group looked up.

"True," the innkeeper's daughter agreed, though she would have admitted that she knew nothing of princes if she had been asked.

A young, haughty lad - that is why the innkeeper's daughter smirked. Haughty lad is a jargonic way to say an arrogant guy. Here we witness verbal irony.

The utterance Well, princes and peasants don't kiss, for one points to the obscene thoughts of the innkeeper's daughter about princes, then she says that a prince can kiss the peasant but that does not mean that he is going to marry her (situational irony). The words of the other woman Probably'd have other things on his mind show the indecency and the lack of intelligence and manners of the 
women in the story, not only the princes they are talking about. In the last two examples we see structural irony as the characters are obviously not aware of what they are talking about, and this is proved in the last example. The happy group is the group that was laughing at what the other woman had said earlier. The happy group is an example of sarcasm pointing to the ignorance of the people in the room. What is said by the innkeeper's daughter is her own fantasies and she is not the expert on princes. So she lightly agrees with a stranger who says that princes can marry anyone. Her remarks show that princes could not marry commoners.

In the following example the stranger (the future prince) uses verbal irony. He admits that the princes choose the most beautiful girls, and if they do not get a title, then the commoners, as he puts it, may seduce them. That is, for him the title is still important and at the same time he admits what the innkeeper's daughter and the other woman had said before.

"...what they do, you see, is they choose the most beautiful maiden, and then they claim she has a title so that other commoners won't be lining up to try to seduce them," the stranger said quietly.

In the next example another case of verbal irony is observed as the innkeeper's daughter is still not sure which side she is on.

"And that, ladies and gentlemen," the innkeeper's daughter announced, "is why you should never trust a prince! Honestly, that can't be true, can it?" she asked the stranger. He stood, drawing back his hood and revealing his golden grown.

The example below is a vivid case of sarcasm. The author of the fanfic mocks all happy endings in tales and claims that all fairy tales roughly end the same way. The author hints that people in the room instead of fairies could become pirates, but since this is a fairy tale, of course, they should turn into fairies.

"You'd best start believing in fairy tales, girl," he growled. "You're in one." Suddenly the moonlight shone into the room, lighting on everyone present. The innkeeper's daughter reeled in shock, and then the whole room turned into pirates - I mean, fairies! 


\section{Conclusion}

The thorough study of fanfic literature, its specific peculiarities, aims and goals, as well as ways and aims of expressing irony namely in fanfic, has brought us to the conclusion that irony is a broad concept with numerous cultural and artistic manifestations such as criticism, sarcasm, humor and may represent various intellectual and emotional states such as criticality, self-criticality, inquisitiveness, amusement, resentment, anger, boastfulness, etc. Fan fiction is closely related to fandom and is usually described as a derivative of a certain media artifact. This means that there ought to be a source-text (if we see every artifact as text, be it literature, TV-shows, videogames, etc.) which creates a response - fan fiction. Irony - widely used in fanfic - is understood by readers who are familiar with the original work. Since it is difficult to express emotions, namely irony, in the written language, fanfic writers may give hints in the form of intonation, context, etc. Nearly all types and sub-types of irony can be found in fanfic: dramatic irony, sarcasm, poetic irony, structural irony, etc.

\section{References}

Derecho, A. (2006). Archontic literature, a definition, a history, and several theories of fan fiction. In K. Hellekson, \& K. Busse (Eds.). Fan fiction and fan communities in the age of the Internet: New essays.(pp. 61-70). Jefferson: McFarland and Co.

Derrida, J. (1995/1996). Archive fever. A Freudian impression. New York, Columbia University Press.

Eiron. (2021). In Encyclopedia Britannica. Retrieved May 12, 2021, from https://www.britannica. com/topic/Eiron

Fowler, H. W. (2003). The King's English. Oxford: Oxford University Press.

Fowler, H. (2015). A dictionary of Modern English usage. Oxford: Oxford University Press.

Irony. (2021). In Wikipedia. The Free Encyclopedia. Retrieved May 19, 2021, from https://en.m. wikipedia.org/wiki/Irony

Partridge, E. (1999). Usage and abusage. UK: Penguin.

Sarcasm. (2021). In Merriam-Webster online dictionary. Retrieved April 25, 2021, from https://www.merriam-webster.com/dictionary/tale

Tale. (2021). In Merriam-Webster online dictionary. Retrieved April 25, 2011, from https://www.merriam-webster.com/dictionary/tale 
Three different types of irony. (2021). In Studiobinder. Retrieved May 1, 2021, from https://www.studiobinder.com/blog/3-different-types-of-irony/

\section{Sources of Data}

Foosemittee. (2013). Fairy tale stereotypes. Retrieved from https://m.fanfiction.net/s/ 8899841/1/Fairy-Tale-Stereotypes.

Masters, J. (2012). An alternet ending. Retrieved from https://www.fanfiction.net/s/6377703/1/An_balternet_b_ending

Orwell, G. (2003). Animal farm and 1984 by George Orwell and A. M. Heath. Boston: Houghton Mifflin.

What ghost Mufasa should have said to Simba. (2011). In Fan Fiction. Retrieved April 25, 2021, from https://www.fanfiction.net/s/9326095/1/What-Ghost-Mufasa-should-have-said-to-Simba

\section{そヒqしUしคূ \$Uし\$กคกhU}

\section{2upnuhh Uiunnijuru}

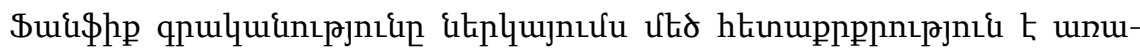

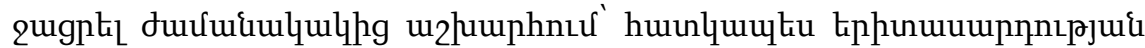

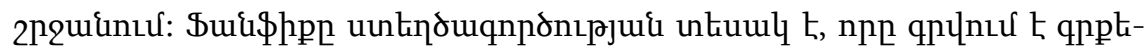

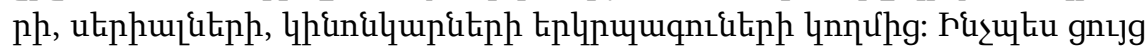

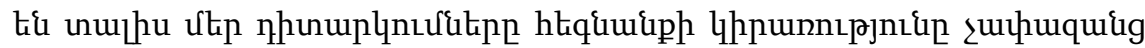

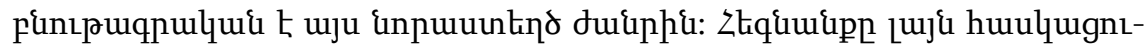

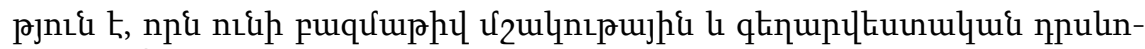

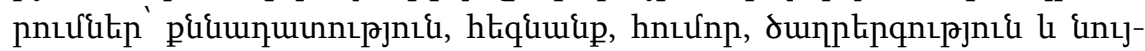

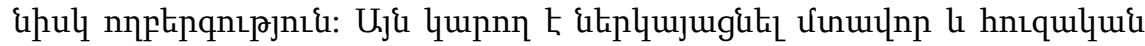

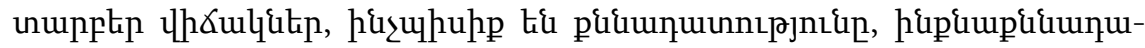

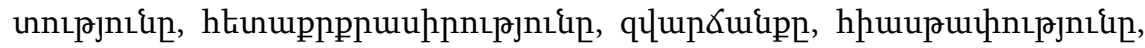

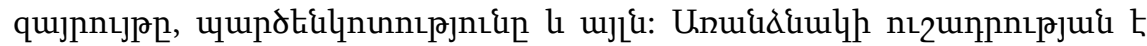

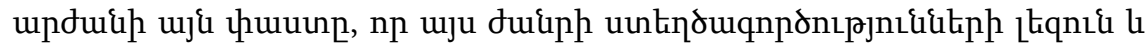

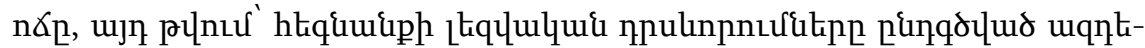

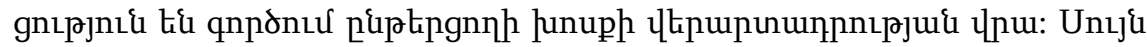

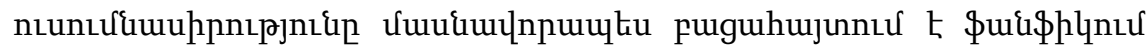

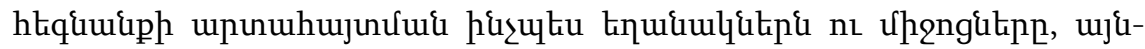

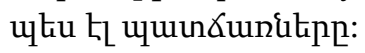

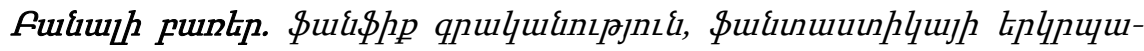

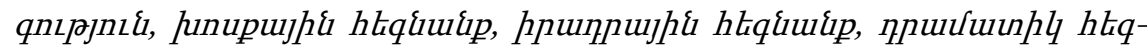
Eumip, uupluwqu: 